\title{
Relevance of pharmacoepidemiology to Nepal
}

\author{
Santosh Thapa ${ }^{1}$, Subish Palaian ${ }^{1,2}$, Hisham Aljadhey³, Pathiyil Ravi Shankar ${ }^{4}$
}

1. Department of Hospital and Clinical Pharmacy, College of Medical Sciences, Bharatpur, Chitwan,Nepal

2. Department of Pharmacology, College of Medical Sciences, Bharatpur, Chitwan, Nepal

3. College of Pharmacy, King Saud University, Riyadh, Kingdom of Saudi Arabia

4. Department of Pharmacology, Xavier University School of Medicine, Aruba, Dutch Caribbean

\section{BRIEF REPORT}

Please cite this paper as: Thapa S, Palaian S, Aljadhey $\mathrm{H}$, Shankar PR. Relevance of pharmacoepidemiology to Nepal. AMJ 2013, 6, 9, 445-449. http://doi.org/10.21767/AMJ.2013.1755

\section{Corresponding Author:}

Santosh Thapa

Department of Hospital and Clinical Pharmacy

College of Medical Sciences, P. O. Box: 23,

Bharatpur, Chitwan, Nepal

Email: santoshthapachettri@gmail.com

\section{Abstract}

Drug-related problems such as overuse of injectable drug products and antimicrobials, increased cost of drug therapy, polypharmacy, and adverse drug reactions (ADRs) are prevalent in the healthcare settings of Nepal. To date, no new drug development processes or clinical trials have been conducted in Nepal, despite the fact that studies of real life situations are an essential tool for monitoring medicine use. Pharmacoepidemiology (PE) is an important area that evaluates the effects of drug use in large populations.

Data obtained from pharmacoepidemiological studies may highlight ways to reduce certain drug-related problems and provide reliable information on the safety profile of a drug. Moreover, clinicians and regulatory authorities may also use the data to make drug therapy decisions, drug regulation and policy development. Therefore, there is a great need to conduct appropriate pharmacoepidemiological studies that involve multiple regions and in various groups of the population of Nepal, to collect unbiased and reliable information on drug use.
Key Words

Clinical decisions, drug regulation, Nepal, pharmacoepidemiology

\section{What this study adds}

1. Data obtained from pharmacoepidemiological studies can provide information about drug use patterns and ADRs in health institutions and the community and promote the rational use of medicines.

2. The present study provides information about selected pharmacoepidemiological studies in Nepal, the approach to pharmacoepidemiological research in the country and expected outcomes of this research.

3. Pharmacoepidemiology has the potential to provide important data about drug use and ADRs in Nepal with important implications for drug use policies and can promote safer and more rational use of medicines by healthcare providers.

\section{Introduction}

Nepal is a landlocked developing country in south Asia, bordered by India and China. Currently, new drug development processes and clinical trials are not being conducted in Nepal. The genetic variations among the population of Nepal are likely to produce more distinct effects than those observed among people involved in the current clinical trials. Overuse of injectable drug products and antimicrobials, ADRs, drug interactions and dispensing drugs to pregnant or lactating women without taking a proper history are some of the drug-related problems that are evident in Nepal. ${ }^{1-4}$

Pharmacoepidemiology (PE) deals with the study of drug effects in a large number of individuals and populations. It applies concepts from clinical pharmacology and epidemiological principles to study the effects of drugs over 
time, thereby forming a bridge between clinical pharmacology and epidemiology. PE has been defined as "the study of the use of and the effects of drugs in large numbers of people with the purpose of supporting a rational and thereby cost effective use of safe and effective drugs in the population". ${ }^{5}$ PE can supplement information obtained from premarketing studies, provide information about previously undetected adverse drug effects, study the patterns of drug use, provide information about the economic aspects of drug use and reassurances about drug safety. ${ }^{6}$ The concept of PE was first introduced in the $1960 \mathrm{~s}$ following an increased emphasis on drug safety and prescribing practices due to the significant adverse effects that restricted the use of drugs like thalidomide. ${ }^{7}$ This concept has since evolved to be a tool for monitoring real world situations such as after drugs are marketed for use. ${ }^{8}$ The application of PE is important in health systems and has been beneficial in reducing drug-related problems in areas of use, as well as in the approval and ultimately for the promotion of rational use of drugs. Developing nations like Nepal have not fully utilised the potential contributions of PE in healthcare settings. ${ }^{9}$ For example, PE studies can aid in the establishment of guidelines in hospitals and also at national level in promoting the rational use of drugs.

Pharmaceutical companies are increasingly involved in pharmacoepidemiologic studies. These companies form alliances with doctors and patient groups and fund studies which exaggerate disease prevalence estimates to show a condition as severe and widespread and requiring treatment. ${ }^{10}$ This has been seen in conditions of erectile dysfunction and bipolar disorder in children. Aggressive pharmaceutical promotion has led to disease mongering wherein common ailments are turned into medical problems which create huge profits for the industry but an economic burden at individual and community level. ${ }^{11}$ Companies have suppressed ADRs of their drug products and exaggerated ADRs of competitor products. A recently published study states that cumulative pooled analysis of all randomised, placebo-controlled trials demonstrated a trend toward increased cardiovascular risk associated with the selective COX-2 inhibitor, rofecoxib compared with placebo as early as December 2000, and the comparison reached a $P$ value of 0.05 by June 2001 , nearly 3.5 years before the manufacturer's voluntary withdrawal of the drug from the market. $^{12}$ Clinical trials with the involvement of pharmaceutical companies often present the therapeutic benefit of a drug positively and fail to mention risks. Published trial results are used by professional medical bodies to construct evidence-based guidelines, so their recommendations may be flawed. This may contribute to excessive prescription of expensive new drugs whose efficacy is overestimated and risks underestimated. ${ }^{13}$

\section{Selected pharmacoepidemiological studies in Nepal}

A Google scholar search (www.scholar.google.com) using the search words (Pharmacoepidemiology, Nepal) and a manual search of existing journals from the institutional library were done during the second and third week of March. The selected articles were discussed among the authors regarding their inclusion in relevant $P E$ studies mentioned in Table 1. The selected PE studies also include the articles obtained during a PubMed search using the search words (Nepal, Pharmacoepidemiology). Priority for selecting relevant studies was given to original articles followed by review articles and short communications.

Most of the PE studies done in Nepal are based on prescribing and drug utilisation patterns and cover almost all of the departments of a hospital as shown in Table 1 . The PE studies address various drug-related problems like prescribing antibiotics without indication, overuse of analgesics, antibiotics and expensive nutritional supplements etc. present in healthcare settings of Nepal. This highlights the need for more PE studies to identify the problems and understand the best methods to manage it for better health outcomes. Most studies mentioned here were conducted in a particular region of the country, which means that the results cannot be applied to the whole country. Additional representative studies of more hospitals throughout multiple regions of the country are still needed.

\section{Approach to pharmacoepidemiological research in Nepal}

The presence of computerised databases that link the data on the use of medicines and patient medical outcomes are still lacking in Nepal and researchers have to rely on paper medical records. Although some hospital pharmacies use software that provides data on drug use, most of them do not provide clinical information for the patients.

Pharmacovigilance, a sub discipline of PE where a suspected adverse drug reaction is reported by healthcare providers, was first introduced in Nepal in 2004 after the Department of Drug Administration (DDA) the drug regulatory body was nominated as the national centre, working closely with the WHO Collaborating Centre for ADR Monitoring in Uppsala, Sweden. ${ }^{14}$ Since then, a number of ADRs have been reported by different centres in the country. This has provided effective data to conduct PE studies in Nepal. Still, this sector lacks adequate co-operation and support from physicians and pharmaceutical companies. In addition, like other developing countries, Nepal lacks qualified personnel, 
efficient networking between hospitals, and awareness among the general public regarding pharmacovigilance. ${ }^{15}$

\section{Expected outcomes of pharmacoepidemiological research in Nepal}

Pharmacovigilance can provide data on the safety profile of drugs and based on this information decisions can be made that supports the protection of human subjects. ${ }^{16}$ In Nepal, the incorporation of PE studies along with the collection of pharmacovigilance data can be used to estimate the prevalence and incidence of adverse effect and hypothesis testing, as well as inform the decision making process on drug withdrawal. The regulatory authority of Nepal, the DDA can make necessary decisions whether or not to approve a particular drug for use from the evidence based data available from PE studies done within Nepal. ${ }^{17}$ Furthermore, PE studies conducted in Nepal may yield use and effect patterns for drugs that can serve as the basis for formulating a drug list and guidelines at local or national levels. Findings from the PE studies may also provide an idea of antibiotic susceptibility, which helps in framing the local and national treatment guidelines for promoting rational use of medicines.

The presence of sound-alike look-alike medicines, use of abbreviations, improper selection of administration devices are the common problems in hospitals of Nepal and may cause medication errors. ${ }^{18}$ In order to study the occurrence and for future prevention of medication errors, PE studies in Nepal would incorporate the good medical record systems, computerised pharmacy systems and data record systems to link these errors with clinical information of the patient. ${ }^{19}$ In addition, PE studies would provide insight into the trends of drug use in a particular hospital and region, which would then support the estimation of drug consumption for a defined period of time. The unbiased and valid information provided by PE studies can be successful in providing the health professional with the best level of evidence for making drug therapy decisions. This would ultimately contribute to an overall improvement of health outcomes. ${ }^{20}$

\section{Conclusion}

PE is a new, emerging area in the medical field that takes lessons from real life. It brings about changes in healthcare settings by providing valid and reliable data that can lead to improvements in the present treatment strategies and new treatment approaches for better health outcomes. Nepal can benefit greatly from the application of PE, which can provide data that support changes in policy development, regulation and decisions on drug-related issues.

\section{References}

1. Kafle KK, Madden JM, Shrestha AD, Karkee SB, Das PL, Pradhan YMS, Quick JD. Can licensed drug sellers contribute to safe motherhood? A survey of the treatment of pregnancy-related anaemia in Nepal. Soc Sci Med 1996;42:1577-88.

2. Joshi MP, Sugimoto $T$, Santoso B. Geriatric prescribing in the medical wards of a teaching hospital in Nepal. Pharmacoepidemiol Drug Saf 1997;6:417-21.

3. Wachter DA, Joshi MP, Rimal B. Antibiotic dispensing by drug retailers in Kathmandu, Nepal. Trop Med Internat Health 1998;4:782-88.

4. Shankar PR, Dubey AK, Rana MS, Mishra P, Subish P and Vijaya Bhaskar P. Drug utilisation with special reference to antimicrobials in a subhealth post in Western Nepal. Journal of Nepal Health Research Council 2005;3:65-9.

5. Bergman U. Pharmacoepidemiology - from description to quality assessment A Swedish perspective. Nor Epidemiol 2001;11:31-6.

6. Strom BL. (Ed.) Pharmacoepidemiology. Fourth edition. 2005: John Wiley and Sons: England.

7. Evans SJW. An agenda for UK clinical pharmacology: Pharmacoepidemiology. $\mathrm{Br} J$ Clin Pharmacol 2012;73:973-78.

DOI:10.1111/j.13652125.2012.04248.x.

8. Fautrel B. Pharmacoepidemiology: lessons from real life. Joint Bone Spine 2004;71:175-77. DOI:10.1016/j.jbspin.2003.07.008.

9. Ansari F. Pharmacoepidemiology in developing countries - What can ISPE do? Pharmacoepidemiol Drug Saf 2000;9:611-13.

10. Moynihan R, Heath I, Henry D. Selling sickness: the pharmaceutical industry and disease mongering. BMJ 2002;324(7342):886-91.

11. Shankar PR, Subish P. Disease mongering. Singapore Med J 2007;48(4):275-80

12. Ross JS, Madigan D, Hill KP, Egilman DS, Wang $Y$, Krumholz HM. Pooled analysis of rofecoxib placebo-controlled clinical trial data: lessons for postmarket pharmaceutical safety surveillance. Arch Intern Med 2009;169:1976-85.

13. Schott G, Pachl H, Limbach U, Gundert-Remy U, Lieb K, Ludwig WD. The financing of drug trials by pharmaceutical companies and its consequences: part 2: a qualitative, systematic review of the literature on possible influences on authorship, access to trial data, and trial registration and publication. Dtsch Arztebl Int 2010;107:295-301.

14. Shankar PR, Jha N. Community pharmacovigilance in Nepal: a guide to community pharmacists. Journal of 
Clinical and Diagnostic Research 2009;3:1379-80.

Available online from:

http://www.jcdr.net/back_issues.asp?issn=0973-

$709 x \&$ year $=2009 \&$ month $=$ February $\&$

volume=3\&issue=1\&page=1379-1380\&id=375.

15. Vaidya SS, Guo JJ, Heaton PC, Steinbuch M. Overview and comparison of postmarketing drug safety surveillance in selected developing and welldeveloped countries. Drug Inf J 2010;44:519-33. DOI: $10.1177 / 009286151004400501$.

16. Waller P. Pharmacoepidemiology- a tool for public health. Pharmacoepidemiol Drug Saf 2001;10:16572. DOI: $10.1002 / p d s .579$.

17. Williams D. Monitoring medicines use: the role of the clinical pharmacologist. $\mathrm{Br} J$ Clin Pharmacol 2012;74:685-90.

DOI:10.1111/j.1365-2125.2012.04316.x.

18. Dubey AK, Palaian S, Shankar PR, Mishra P, Prabhu

$\mathrm{M}$, Bhandari RM, Chhetri AK. Introduction to

medication errors and the error prevention

Initiatives in a teaching hospital in western Nepal.

Pak J Pharm Sci 2006;19:244-51.

19. Etminan M, Gill S, FitzGerald M, Samii A. Challenges and opportunities for pharmacoepidemiology in drug-therapy decision making. J Clin Pharmacol 2006;46:6-9. DOI:10.1177/0091270005283285.

20. Das B, Sarkar C, Datta A, Bohra S. A study of drug use during pregnancy in a teaching hospital in Western Nepal. Pharmacoepidemiol Drug Saf 2003;12:221-25. DOI:10.1002/pds.770.

21. Sarkar C, Das B, Baral P. Analgesic use in dentistry in a tertiary hospital in Western Nepal. Pharmacoepidemiol Drug Saf 2004;13:729-33. DOI: 10.1002/pds.972.

22. Shankar PR, Subish P, Upadhyay DK, Dubey AK, Deshpande VY. Cephalosporin utilisation in the inpatient wards of a teaching hospital in Western Nepal Pharmacoepidemiol Drug Saf 2005;14:507-8. DOI: $10.1002 / p d s .1090$.

23. Lamichhane DC, Giri BR, Pathak OK, Panta OB, Shankar PR. Morbidity profile and prescribing patterns among outpatients in a teaching hospital in Western Nepal. Mcgill J Med 2006;9:126-33.

24. Shankar PR, Upadhyay DK, Mishra P, Subish P, Dubey AK, Saha AC. Fluoroquinolone utilisation among inpatients in a teaching hospital in Western Nepal. J Pak Med Assoc 2007;57:78-82.

25. Thapa RK, Bhandari B, Adhikari K, Katila P, Baral P, Khan GM. Antibiotic prophylaxis in caesarean section. International Journal of Public Health Science 2012;1:1-6.
26. Sah AK, Yadav SK, Sah P, Jha RK. Prescribing trends of non-steroidal anti-inflammatory drugs used in dental outpatient department of a tertiary hospital in Nepal. J Pharm Sci Res 2012;4:1779-82.

\section{PEER REVIEW}

Not commissioned. Externally peer reviewed

\section{CONFLICTS OF INTEREST}

The authors declare that they have no competing interests. 
Table 1: Selected pharmacoepidemiological studies in Nepal

\begin{tabular}{|c|c|c|c|c|}
\hline S. No. & Author (s) & Objective & Method & Findings \\
\hline 1 & $\begin{array}{l}\text { Das B et al, } \\
2003^{20}\end{array}$ & $\begin{array}{l}\text { To gain knowledge } \\
\text { on drug use during } \\
\text { pregnancy }\end{array}$ & $\begin{array}{l}\text { Random once weekly survey } \\
\text { of prescriptions of pregnant } \\
\text { women during a year }\end{array}$ & $\begin{array}{l}\text { Most prescribed drugs were } \\
\text { nutritional supplements like iron, } \\
\text { folate, calcium, vitamins. Average } \\
\text { number of drugs per prescription was } \\
2 .\end{array}$ \\
\hline 2 & $\begin{array}{l}\text { Joshi MP et al, } \\
1997^{2}\end{array}$ & $\begin{array}{l}\text { To study prescribing } \\
\text { patterns in geriatric } \\
\text { patients }\end{array}$ & $\begin{array}{l}100 \text { randomly selected } \\
\text { prescriptions of geriatric } \\
\text { patients admitted during a } \\
\text { year were analysed }\end{array}$ & $\begin{array}{l}73 \% \text { of the patients received more } \\
\text { than five drugs. IV fluids were the } \\
\text { most prescribed drugs ( } 91 \% \text { ) with } \\
\text { antibiotics being the second. }\end{array}$ \\
\hline 3 & $\begin{array}{l}\text { Sarkar C et al, } \\
2004^{21}\end{array}$ & $\begin{array}{l}\text { To determine pattern } \\
\text { of drug utilisation of } \\
\text { analgesics in dental } \\
\text { outpatients }\end{array}$ & $\begin{array}{l}\text { Random once weekly survey } \\
\text { of prescriptions of a year was } \\
\text { done }\end{array}$ & $\begin{array}{l}74 \% \text { of the prescriptions contained } \\
\text { analgesics. Ibuprofen ( } 41 \% \text { ) and } \\
\text { paracetamol + propoxyphene ( } 56 \% \text { ) } \\
\text { were the most prescribed non-opioid } \\
\text { and opioid analgesic respectively. }\end{array}$ \\
\hline 4 & $\begin{array}{l}\text { Wachter DA et } \\
\text { al, } 1999^{3}\end{array}$ & $\begin{array}{l}\text { To study dispensing } \\
\text { of antibiotics by } \\
\text { community } \\
\text { pharmacies }\end{array}$ & $\begin{array}{l}100 \text { randomly selected } \\
\text { prescriptions in two months } \\
\text { were studied }\end{array}$ & $\begin{array}{l}97 \% \text { of the community pharmacies } \\
\text { dispensed unnecessary antibiotics for } \\
\text { diarrhea. Most of them lack adequate } \\
\text { knowledge about disease process and } \\
\text { most dispense irrationally. }\end{array}$ \\
\hline 5 & $\begin{array}{l}\text { Shankar PR et } \\
\text { al, } 2005^{22}\end{array}$ & $\begin{array}{l}\text { To study utilisation } \\
\text { patterns of } \\
\text { cephalosporins }\end{array}$ & $\begin{array}{l}\text { Case records of admitted } \\
\text { patients in inpatient ward } \\
\text { during a period of four months } \\
\text { were analysed }\end{array}$ & $\begin{array}{l}\text { Cephalosporins were most prescribed } \\
\text { in surgery followed by medicine } \\
\text { department. Most of them (46.8\%) } \\
\text { were used for prophylaxis. } \\
\text { Cephalosporin utilisation was } 4.6 \\
\text { DDDs/100 bed-days. }\end{array}$ \\
\hline 6 & $\begin{array}{l}\text { Lamichhane DC } \\
\text { et al, } 2006^{23}\end{array}$ & $\begin{array}{l}\text { To study morbidity } \\
\text { and prescribing } \\
\text { patterns in } \\
\text { outpatients }\end{array}$ & $\begin{array}{l}\text { Every 20th patient following } \\
\text { the first number chosen } \\
\text { among outpatients who } \\
\text { visited the OPD during a year } \\
\text { were analysed. }\end{array}$ & $\begin{array}{l}\text { Upper respiratory tract infection and } \\
\text { acid peptic disease were the most } \\
\text { common diagnoses and mean } \\
\text { number of drugs used was } 1.99 \text {. } \\
\text { Antihistamines were the most } \\
\text { prescribed drug category followed by } \\
\text { NSAIDs. }\end{array}$ \\
\hline 7 & $\begin{array}{l}\text { Shankar PR et } \\
\text { al, } 2007^{24}\end{array}$ & $\begin{array}{l}\text { To study prescribing } \\
\text { patterns of } \\
\text { fluoroquinolones } \\
\text { among hospitalised } \\
\text { patients }\end{array}$ & $\begin{array}{l}\text { Inpatients enrolled during a } \\
\text { period of five months and } \\
\text { prescribed with } \\
\text { fluoroquinolone were } \\
\text { analysed }\end{array}$ & $\begin{array}{l}\text { Fluoroquinolone utilisation was } 7.76 \\
\text { DDD/100 bed-days and contributed } \\
\text { to } 36.7 \% \text { of the total drug costs and } \\
\text { ciprofloxacin was the most prescribed } \\
\text { fluoroquinolone. }\end{array}$ \\
\hline 8 & $\begin{array}{l}\text { Shankar PR et } \\
\text { al, } 2010^{4}\end{array}$ & $\begin{array}{l}\text { To study drug } \\
\text { utilisation in older } \\
\text { inpatients }\end{array}$ & $\begin{array}{l}\text { Case records of discharged } \\
\text { patients older than } 60 \text { years } \\
\text { during a year were analysed. }\end{array}$ & $\begin{array}{l}\text { Higher number of drugs especially } \\
\text { parenteral and IV fluids were } \\
\text { prescribed. }\end{array}$ \\
\hline 9 & $\begin{array}{l}\text { Thapa RK et al, } \\
2012^{25}\end{array}$ & $\begin{array}{l}\text { To study the use of } \\
\text { antibiotics } \\
\text { prophylaxis in } \\
\text { Caesarean section }\end{array}$ & $\begin{array}{l}\text { Non-randomly selected } \\
\text { women undergoing Caesarean } \\
\text { section for a period of three } \\
\text { months were analysed }\end{array}$ & $\begin{array}{l}\text { The most prescribed antibiotic was } \\
\text { metronidazole }(99.5 \%) \text { followed by } \\
\text { ciprofloxacin and gentamicin ( } 50.5 \% \\
\text { each). }\end{array}$ \\
\hline 10 & $\begin{array}{l}\text { Sah AK et al, } \\
2012^{26}\end{array}$ & $\begin{array}{l}\text { To monitor } \\
\text { prescribing pattern } \\
\text { of NSAIDs in dental } \\
\text { outpatients }\end{array}$ & $\begin{array}{l}\text { Randomly selected } \\
\text { prescriptions of dental OPD for } \\
\text { a period of } 6 \text { months were } \\
\text { analysed }\end{array}$ & $\begin{array}{l}\text { Ibuprofen + paracetamol ( } 48.4 \%) \text { was } \\
\text { the most prescribed NSAID followed } \\
\text { by piroxicam }(31 \%)\end{array}$ \\
\hline
\end{tabular}

IV- Intravenous; DDD- Defined Daily Dose; NSAIDs- Non Steroidal Anti-Inflammatory Drugs; OPD- Out-Patient Department 